Obituaries

\section{Dr A. D. Wadsley}

ON January 6, 1969, Arthur David Wadsley died suddenly in Canberra while chairing the opening session of an international symposium on phase transformations and the Earth's interior.

Born in Hobart in 1918, Wadsley studied metallurgy and chemistry at the University of Tasmania (BSc, 1940; MSe, 1942; DSc, 1956). An interest in chemical crystallography-to become the dominant feature of his career-arose from early research on manganese dioxide in the Minerals Utilization Section of the Division of Industrial Chemistry, Council for Scientific and Industrial Research. Intrigued by his failure to develop a suitable manganese dioxide for dry cells from an anode "mud" produced in the Tasmanian plant of the Electrolytic Zinc Company of Australasia, Wadsley spent five years studying the structure and reactivity of the oxides of manganese and related compounds.

His reporting of this work, comprising brief notes in Nature $(170,973 ; 1952: 172,1103 ; 1953)$ and lengthier papers in specialist journals (Acta Cryst., 6, 433; 1953: 8,$165 ; 1955:$ J.Chem. Phys., 22, 346; 1954) set a characteristic pattern for his subsequent publications. At this time, as he laid the foundation for his work on nonstoichiometric compounds, his thinking was influenced by the results of Scandinavian research. This was particularly noticeable in his first paper on the concept of crystallographic shear (Rev. Pure and Appl. Chem., 5, 165; 1955).

When, in 1959, the Minerals Utilization Section was constituted as the Division of Mineral Chemistry, Commonwealth Scientific and Industrial Research Organization, Wadsley became the centre of a widespread programme of collaboration with both Australian and international research workers. Some of this activity was reflected in a series of communications to Nature. Simultaneously he accepted an increasingly heavy administrative load and was appointed Chief Research Scientist in 1964 and Assistant Chief of the Division in 1967.

Throughout his scientific career, one of Wadsley's chief driving forces was the desire to bring order into work associated with "defects" in the non-stoichiometric oxides and related compounds of titanium, vanadium, niobium, tantalum, molybdenum and tungsten. $\mathrm{He}$ constantly referred to the time when inorganic chemists would be able to design new structures in the solid state at will, and sought the principles which would make this possible. During the Werner centenary celebrations he summarized his work on compounds of the transition metals by claiming that a polyhedron, centred around a transition metal ion in its maximum valency state, is attracted towards similar polyhedra, and unites with them so as to have the maximum edge or face-sharing com. patible with the stoichiometry of the phase in which it occurs (Helv. Chim. Acta. Fasciculus extraordinarius Alfred Werner, 207; 1967). On this postulate of stable polyhedral groups, Wadsley based his many contributions to the "block" theory of structure, and an extensive review of this work is scheduled to appear in Perspectives in Chemistry.

Just before his death he was delighted to hear that one of the three principal interests of the new Journal of Solid State Chemistry was to be solid state synthesis and characterization, and he accepted an appointment on the editorial board. His posthumous publications on the nature of defects revealed by electron microscope fringe patterns will appear in that journal and in Acta Crystal. lographica. They will provide a reminder of a career which was tragically terminated in its prime.

\section{Dr Ellen Gleditsch}

THE rapid development of the nuclear sciences in the past fow decades has tended to obscure the memory of the pioneers who laid the foundations and were instrumental in the early development of the subject. Ellen Gleditsch, who died in Oslo during the summer of 1968, was one of those pioneers. She was the first student of Madame Curie, from 1907 to 1912.

Great confusion confronted scientists at that time, before the concept of isotopy had been recognized. It was easy to place the newly discovered polonium in the periodic system, and also actinium, but what was to be done with ionium (Th-230), radiothorium (Th-228) and radioactinium (Th-227), the active deposits ? To bring some kind of order into this chaos it was necessary to know the physical and chemical properties of these elements, their relationships with other elements and their abundance in nature. The origin of actinium and its ratio to uranium in different minerals was Ellen Gleditsch's special interest. She found a 5 per cent ratio of actinium to uranium, instead of 0.15 per cent in the two Norwegian minerals broggerite and cleveite. She determined the ratio of radium to uranium to almost the value accepted today. The same goes for the half life of radium and the age of minerals; she realized the value of the radioactive property of potassium in geophysics. Soon after the discovery of isotopy her interest was directed towards the determination of the atomic weight of lead and chlorine isotopes separated from uranium minerals. These were the results of her early work during the time which is often called the "heroic" period of the nuclear sciences.

Ellen Gleditsch was Licenciée en Sciences at the Sorbonne in 1912, doctor honoris causa from Yale University in 1913-14, and honorary doctor of the University of Strasbourg. She was associate professor of chemistry at the University of Oslo from 1916 to 1929 , professor from 1929 to 1946 and professor emeritus from 1946.

After her retirement, Ellen Gleditsch was busy lecturing and writing biographical essays of the Curies, Lavoisier, Gay Lussac and Saint DeVille. France was her second home, to which she returned regularly, and where she was the first woman to receive an honorary doctorate from the Sorbonne. She was also honoured with the Legion d'Honneur.

\section{Correspondence}

\section{Coalfield Exploration}

SiR,--While agreeing with Spink that an authoritative study of the extremely interesting and varied coalfields of Leicestershire and South Derbyshire would be most desirable, I would suggest that his article published in Nature $(220,129 ; 1968)$ is perhaps somewhat lacking in objectivity, with goneralities not always fully supported by facts.

No exception is taken to much of the factual informa. tion published in the article, but I must draw attention to some statements which seem to require more detailed examination and discussion. It is, for example, very much doubted whether there is, in fact, a paucity of marine or "mussel" bands in this area and I also believe many geologists would agree that there is an over-emphasis on earth movements deduced from sedimentological information, indicating that insufficient weight has been given to 